\title{
Were the Yeshivot in Spain Centers for the Copying of Books?*
}

Michael RIEGLER

The Jewish National and University Library, Jerusalem

\section{INTRODUCTION}

Paleographers estimate the number of dated Hebrew manuscripts from 3,000 to $5,000{ }^{1}$. Due to the broad geographical dispersion of the Jews, these manuscripts were copied in many lands. The diverse range of Hebrew scripts developed in the Middle Ages does not correspond to geographical or political boundaries, as could have been expected. The high mobility of the Jews -either voluntary or forced- led to a situation in which a writing type which developed in one Jewish cultural milieu appeared in another different one a few years later ${ }^{2}$.

The Spanish writing developed in the Iberian Peninsula took

\footnotetext{
* I would like to thank my colleague Dr. Avraham David, who drew my attention to several important bibliographical items.

${ }^{1}$ Of the approx. 50,000 written until 1540. See M. BEIT-ARIÉ, "The Hebrew Palaeography Project", Ha-Universitah 3 (1967) pp. 53-58.

${ }^{2}$ Thus, e.g.: a) MS Paris, Bibliothèque Nationale, Héb. 402, copied in Iesi (Italy) in 1473, in Ashkenazic script; see the description M. BEIT-ARIÉ and C. SiRAT, Manuscrits Médiévaux en Caractères Hébraïques (Jerusalem - Paris 19721979) vol. 1 no. 134); b) MS Paris, Bibliothèque Nationale, Héb. 790, copied in 1401 in Negroponte (Greece), in Spanish (and not Byzantine) script; see the description in BeIT-Arié - Sirat Manuscrits vol. 1 no. 7; c) MS Paris, Bibliothèque Nationale, Héb. 998, copied in Italy in 1480, in Ashkenazic and Spanish scripts by a few scribes; for details of the manuscript, see BEIT-ARIE SIRAT Manuscrits vol. 3 no. 20.
} 
different forms (square, semi-cursive, or cursive) ${ }^{3}$. It was not exclusive of the scribes in this region, but was also used in other areas under the cultural influence of Spanish Jewry, such as the provinces of southern France beyond the Pyrenees, Provence and Languedoc, the lands of northern Africa, and the lands politically subservient to the Spanish kingdoms, such as southern Italy and Sicily. The Spanish script was spread in other lands by immigrants, and rapidly attained prominence in the neighboring countries around the Mediterranean basin. This expansion reached its peak after the Expulsion from Spain, when the exiles arrived in the lands of the Ottoman Empire. The distribution of the Spanish script provides new testimonies of the importance of Spanish Jewry, its intellectual level, and the degree of influence it exerted in the communities throughout the Jewish diaspora. The extant Hebrew manuscripts written in this script -approx. one thousandare about one third of all the known dated manuscripts copied by $1540^{4}$.

About 250 out of the bulk of the manuscripts written in the Spanish script were copied in Spain until the time of the Expulsion, and they clearly reveal the place of copy ${ }^{5}$. The manuscripts were copied by professional copyists for different patrons, or by Torah scholars for their own needs. A comparison of the styles of script used in these manuscripts reveals that more than 50 of them were copied by a few (from two to eight) scribes sharing their work. The copying work was done either simultaneously (the text was apportioned to the copyists and each one copied his own portion), or consecutively (by different scribes one after the other). The identity of the partners of the chief scribe is unknown. They were probably the elder sons of the scribe who were proficient in the skill of writing, or the pupils who copied either for their teacher or for one of the other pupils in the yeshivah. This datum is

\footnotetext{
${ }^{3}$ See M. BeIT-ARIÉ, “Ketav Ivri», in Ha-Enziklopedyah ha-Ivrit vol. 26 (Jerusalem 1974) cols. 631-634; and A. YARDENI, The Book of Hebrew Script (Jerusalem 1991) pp. 76-90.

${ }^{4}$ M. BeIT-ARIÉ, "The Codicological Data-Base of the Hebrew Palaeolography Project", British Library Occasional Papers 13 (1991) pp. 165-181.

5 According to the colophons, the Hebrew manuscripts were copied in 83 cities and towns all throughout Spain. See H. BeinarT, Atlas of Medieval Jewish History (New York 1992) p. 56. (This map is based on my research for this atlas.)
} 
indicated by some colophons from "Spanish" manuscripts. A similar phenomenon occured in other copying centers.

As is illustrated by three colophons from Spanish manuscripts, the names of the participants in the production of books rarely appear in them. In most cases, only the name of the scribe who wrote the colophon is mentioned. He was probably the chief scribe, or the last copyist who completed the labor of writing. This practice varies from one book to another.

From 1480 to 1481, three scribes in Fromista copied the Commentary of Ha-Meiri (Menahem b. Solomon, 1249-1316) on the book of Psalms for R. Abraham Meir b. Judah Meir. The writing styles indicate that the second scribe, named Judah, wrote the following colophon:

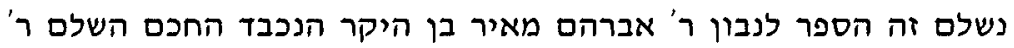

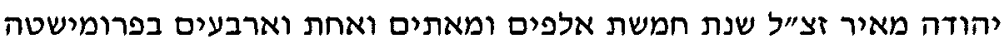

על ידי יהודה.

This book has been completed, for the wise R. Abraham Meir, the son of the precious and distinguished perfect scholar R. Judah Meir, of blessed memory, in the year five-thousand two-hundred and forty-one [5241/=1480-81], in Frómista, by Judah ${ }^{6}$.

The name of the first scribe has not been elucidated, but the third one's was "Isaac", as is remarked several times in the text. The three scribes copied the book simultaneously, and replaced one another quite frequently, at times within the same page.

A 1485 manuscript containing the Ohev Mishpat by R. Simeon Duran (1361-1444), a commentary on Job, was copied by three different scribes for Isaac b. Abraham ha-Kohen. Although the colophon does not mention the venue of the copying, the rabbinical Spanish script enables us to establish almost certainly that the labor of copying took place in one of the communities in the Iberian Peninsula. The author of the colophon, the third scribe, Joseph b. Eli b. Israel, provided the following details:

נשלם על ידי אני הצעיר זה הספר הנכבד לאשר ניתן כתר תורה על ראשו

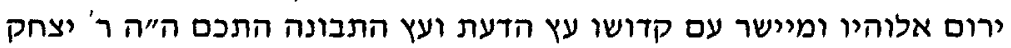

${ }^{6}$ MS Oxford, Bodleian Lib., Opp. 213, fol. 140r. 


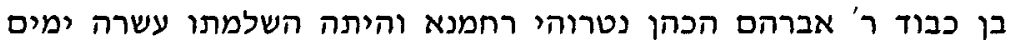

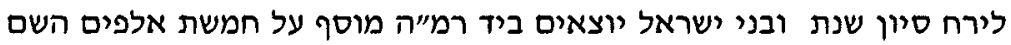

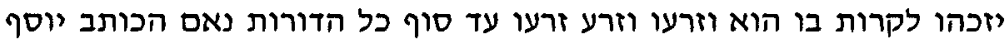

בר עלי ס״ט לקרות בן ישראל.

This distinguished book was completed by me, the young one, for that one wearing the crown of the Torah on his head, exalted by his God, who judges his Holy people [cf. Ps 67:5], the tree of knowledge, and the tree of discernment, the scholar, the magnificent rabbi $R$. Isaac, the son of the honored R. Abraham ha-Kohen, may the Merciful One preserve him. And it was completed on the tenth day of the month of Sivan [ $=24$ th of May], in the year "for the Children of Israel went out with extended [v"nr = 245] hand" [Ex 14:8], in addition to the five thousand [years] [5245/=1485]. May the Lord grant him merit to read it, he and his offspring and his offspring's offspring until the end of all generations. Spoken by the writer Joseph b. Eli (may he come to a good end) b. Israel ${ }^{\text {. }}$.

The changes in the script indicate that the manuscript was copied by three different scribes. This is also the case of other manuscripts written by more than a single scribe.

In 1491, the Hebrew translation of the book Ha-Mistikah leAristo was copied in the city of Ocaña for an unknown individual. The colophon does not mention the names of the copyists, nor that of the colophon's author. A comparison of the script types shows that the book was copied by no fewer than seven scribes replacing one another. The scribe who wrote the colophon provides the following details:

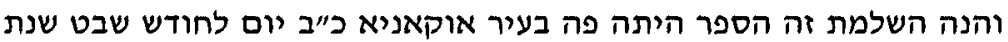

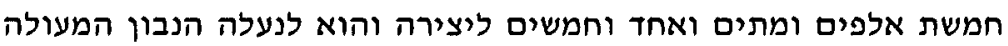

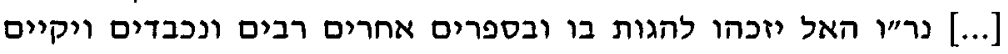

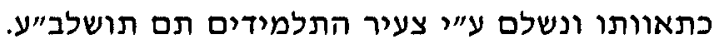

Behold, the completion of this book was in the city of Ocaña, the 22nd day of the month of Shevat [= second day of Feb.], in the year five-thousand and two-hundred and fifty-one $[5251 /=$ 1491] of the Creation, for the exalted, discerning and excellent [erased], may God preserve him. May God allow him to study it and many other distinguished books, so that he may fulfil his

${ }^{7}$ MS Oxford, Bodleian Lib., Or. 84, fol. 227v. 
wishes. This was completed by the youngest of the pupils. Done. Done and completed, praised be the Lord Creator of the Universe ${ }^{8}$.

As we know from the world of the Greek and Latin book, most of the medieval book copying was carried out within an institutional context, such as the Christian scriptorium, which was an adjunct of large and well-known monasteries ${ }^{9}$. In the scriptorium, the monks copied books as part of their religious duties ${ }^{10}$. This work was performed by individuals or groups of monks. When the copying work was to be completed under pressure, the number of copyists could be several dozens. When the first universities in Europe opened in the mid-thirteenth century ${ }^{11}$, book production work was transferred to these institutions, and later to the bookstores, which also dealt with the copying of books, and not merely with their sale.

The copying of books in Arabic was done in a similar way. These books were copied by a professional scribe (al-warak), in a maktaba, i.e., an educational and cultural institution. Books were copied for those who requested this service, and writing instruments and tablets were provided ${ }^{12}$.

\section{The Location of the Copying of Hebrew Books}

Did institutionalized frameworks, similar to those for Greek, Latin, and Arabic books, come into being throughout the Middle Ages? Or, was there a unique reality prone to external influences in the world of the Hebrew copyists?

There are no testimonies to the existence of institutionalized copying centers in which Hebrew books were produced. The literary sources which mention the labor of Hebrew book copying are also silent regarding the place of this activity ${ }^{13}$. This fact

\footnotetext{
${ }^{8}$ MS London, Jews' College 296, fol. 303r.

9 F. DE-Roover, "The Scriptorium», in The Medieval Library (Chicago 1939) pp. 594-612.

${ }^{10}$ G. H. Putnam, Books and Their Makers during the Middle Ages (New York 1896) vol. 1 pp. 67-88; J. IrigoIN, "Centres de copie et bibliothèques", in Byzantine Books and Bookmen, Dumbarton Oaks Colloquium, 1971 (Washington D.C. 1975) pp. 17-27.

${ }^{11}$ Dictionary of the Middle Ages (New York 1989) vol. 12 pp. 282-302.

12 J. Pedersen, The Arabic Book (Princeton 1984) pp. 37-53; and J. M. F. JAmiL, Islamic Wiraqah 'Stationery'during the Early Middle Ages (Ph. D. diss. University of Michigan 1975) pp. 148-198.

${ }^{13}$ R. Judah b. Samuel he-Hasid (1150-1217), the author of the Sefer Hasidim, devotes many sections to the scribes and books in his Ashkenazic environment, but
} 
enhances the importance of the Hebrew colophons, because they shed light upon this issue, and thereby enable us to draw a picture of the life and activity of the Hebrew copyists throughout the entire era of the handwritten Hebrew book. It should be noted that the copyist who wrote a colophon at the end of a manuscript intended to emphasize and perpetuate facts of importance to him, such as the land or city of his activity, as well as exceptional details, such as historical events, and natural disasters. Most colophons make no mention of the exact location of the actual copying. In this case, we assume that this work was completed at the home of the copyist. When he was active in a different venue, such as in the home of the patron, the synagogue, the bet midrash, or somewhere else ${ }^{14}$, the scribe made note of it, since this information was exceptional, wishing to preserve it for the future.

Historical sources from the Franco-German centers show that yeshivah students helped their teachers copy the latter's works, or write responses to queries. The testimony of R. Israel Isserlein (d. 1460) indicates that his pupil copied rulings for him, since «he was not able to write quickly", whereas his pupil would write "at times for free, and at other times for money" ${ }^{15}$. The testimony of Maharam Mintz (d. 1508) reads: «... the emissary must remain until midnight, until the young man copies what you wrote for me in order" ${ }^{16}$. From other sources, we learn that yeshivah students spent much of their time copying and writing religious tracts for their personal use; as the Maharam (Meir b. Baruch) of Rothenburg (Ashkenaz 1215?-1293) read, "their writing is their study" ${ }^{17}$. Moreover, due to the great cost and value of the books, kuntresim

not a single word regarding the location of the copying centers; see ed. J. WisTINETZKi (Frankfurt a.M. 1924) pp. 171-186. Rabbenu Gershom's statement indicates that schoolteachers copied books in the classroom, for purposes of instruction: «The teachers of children and scribes have to be careful to do their work accurately ... If this Reuben [i.e., party X] writes books for himself while the other children are occupied with their affairs, he is permitted to do so", Teshuvot Ragmah, ed. Sh. Eidelberg (New York 1955) § 72.

${ }^{14}$ A number of manuscripts were copied while the scribes were in prison, e.g.: "when I was in prison in the city of Bologna" (MS Paris, Bibliothèque Nationale, Héb. 814, copied in 1403; for a full description, see BEIT-ARIÉ - SIRAT Manuscrits vol. 1 no. 79).

${ }^{15}$ Sefer Leket Yosher (ed. Mekize Nirdamim, Berlin 1903) p. 3.

${ }^{16}$ Sheelot u-Teshuvot Mahari Mintz (Jerusalem 1991) vol. 1 p. 301, 873.

${ }^{17}$ Sheelot u-Teshuvot Maharam me-Rothenburg (Lemberg 1860) p. 8a, § 119. 
('notebooks') containing new instructions and additions by their teachers were quite common among the pupils, but the analysis of these kuntresim exceeds the scope of the current essay. We are concerned here with the production of books in the yeshivot by professional scribes for patrons, for pay or not.

The collection of books in the yeshivot undoubtedly constituted an inexhaustible fountain of material for scribes and copyists to be copied. In the Sefer Yuhasin (fourth essay) by R. Abraham Zacuto, we find the following excerpt about R. Samuel ha-Nagid:

he acted on behalf of Israel in Spain and in the land of the West ... and he would expend his money on those who wished to study the Torah as a full-time occupation. He had scribes and writers of the Mishnah and the Talmud, and gave [the copies] to the students who could not afford to purchase them either in the yeshivot of Spain or in other lands as a gift ${ }^{18}$.

Another testimony from Italy relates that R. Joseph Castelfranco ${ }^{19}$ (first half of the sixteenth century) was appointed head of the yeshivah in Brescia, in northern Italy,

and he had more than one-hundred students. He did great things, and decided to write all the tractates -the Gemara, Commentary [of Rashi] and Tosafot- by hand on parchment. He employed R. Perez ${ }^{20}$, the scribe, to write them for him, and gave him 37 flowers per Sabbath ${ }^{21}$ and his maintenance for [a period of] a year. He should write for him 7 hours a day and 4 hours on Thursdays ${ }^{22}$.

A lamentation composed by R. Abraham Bacrat ${ }^{23}$ after the Expulsion from Spain mourns the abandonment of orderly and

${ }^{18}$ Ed. Z. FilipowsKi (London 1857) p. 211.

${ }^{19}$ R. Joseph (Juspa) b. Samuel, a rabbi in Mantua and in Brescia. See the references to him in S. SimonsoHn, History of the Jews in the Duchy of Mantua (Jerusalem 1964) vol. 2 p. 543.

20 In this period, eleven scribes named Perez were active in Italy. See A. Freimann, "Jewish Scribes in Medieval Italy", in A. Marx Jubilee Volume (New York 1950) pp. 300-309 (nos. 398-403).

21 I.e., 37 florins per week.

22 N. Porgès, "Élie Capsali et sa Chronique de Venise: Pièces justificatives", REJ 79 (1924) pp. 28-60: pp. 44-45; the version in the Seder Eliyahu Zuta, ed. M. BeNAYAHU (Jerusalem 1977) vol. 2 p. 258 says: "he would write for him 8 hours a day and 4 hours on Fridays, and he would order very fine parchment [sheets]".

23 See Encyclopaedia Judaica (Jerusalem 1971-1972) vol. 11 col. 166. 
excellent yeshivot, filled with books, Sifre and Sifra, chambers of documents, and the Torah Ark" ${ }^{24}$.

Thus, throughout the entire Jewish diaspora the yeshivot were one of the institutions, in addition to the synagogues and study halls, in which the copying of books took place on an intensive basis.

This situation is confirmed by Hebrew manuscript colophons in which the copyists inform us of their place of work. Testimonies of these circumstances appear in twenty colophons from throughout the Jewish world. Although not numerous, these testimonies are of great interest for they shed light on the activity of individuals and groups, as well as on the method of copying in the yeshivot. Twelve of these twenty manuscripts were copied in Spanish yeshivot, whereas three were written in Italy, and five were produced in other lands ${ }^{25}$.

From the mid-fifteenth century until shortly before the Expulsion from Spain is a relevant period, because at the time the Spanish yeshivot were prospering, despite the severe persecutions suffered by the Jews from 1391 onward. The existence of a large number of yeshivot throughout Spain points to a rapid cultural recovery of cities with a Jewish population of only a few dozen families ${ }^{26}$. The prestige of the large and well-known cultural centers in Toledo, Sevilla, Burgos, and other locations decreased, and their cultural life diminished. This activity was then transferred from the large cities to towns distant from the former centers ${ }^{27}$.

Spanish-Jewish intellectuals living in and after the generation of the Expulsion gave evidence of the situation of the yeshivot in Spain. R. Joseph Jabez (d. 1507), one of the leading scholars of the Spanish Jewry in the Expulsion generation, wrote: "From ancient times, Spain was not so abundant in yeshivot and pupils as it was at the time of the Expulsion. Some of them [the pupils] study with the great rabbis for six or seven years, and sharpen

${ }^{24}$ H. H. BEN-SAsson, "An Elegy on the Expulsion from Spain", Tarbiz 31 (1961) pp. 59-70: pp. 68-69.

${ }_{25}$ Italy: 1452, 1455, 1487; North Africa: 1524, 1532; the Land of Israel: 1524; the Byzantine area: 1489 .

${ }^{26}$ For the size of the Jewish population in different cities in Spain, see Y. BAER, A History of the Jews in Christian Spain (Philadelphia 1966) pp. 189-196.

27 BAER History p. 365. 
their intellect as a keen sword" ${ }^{28}$. R. Judah Khalaz, a scholar who left Spain a few years before the Expulsion to settle in North Africa, stated: "The land of Castile is a land of yeshivot and pupils" ${ }^{29}$.

Such was the intellectual atmosphere that nurtured the yeshivot where the copyists produced their Hebrew manuscripts. The copying of books for one's personal use is not of our concern here. Both the teacher and his pupils needed books; consequently, they were permitted to copy what they required from the collections of books at their disposal in the bet midrash. Our discussion will focuss rather upon the copying of books to be used by others.

The colophons dealing with the copying of books in the yeshivot reveal details of interest beyond the simple geographical notation of the city in which the yeshivah was located ${ }^{30}$. The copyists tell who the head rabbi of the yeshivah was, and which books were copied. The most important detail is that colophons identify the pupils of these yeshivot, and all this information is derived from a firs-thand source. The names of the outstanding Spanish scholars and the yeshivot in which they acquired their rabbinical education are known from different historical sources. Thanks to these colophons, additional names are provided, some obscure and difficult to identify. However, this information is a significant

\footnotetext{
${ }^{28}$ Sefer Or Hayyim (Amsterdam 1781) p. 2a.

${ }^{29}$ Mesiah Ilemim on Rashi's Bible Commentary (Jerusalem 1986) pp. 10-24: pp. 10-11. For the Khalaz family, see AD. Neubauer, "Documents inédits", REJ 5 (1882) pp. 41-56: "IV: La famille כלץ pp. 47-52; S. Z. HavliN, "On the Khallas Family and the Authorship of the "Maggid Mishne" on Maimonides' "Hilkhot Shehitah" ", Kiryat Sefer 49 (1974) pp. 643-656: pp. 643-649 (with an extensive bibliography about the family); A. GRoss, "R. Yehuda Khalaz in Tlemcen: Judeo-Iberian Culture in North Africa", in Exile and Diaspora: Studies in the History of the Jewish People Presented to Professor Haim Beinart on the Occasion of his Seventieth Birthday, eds. A. Mirsky et al. (Jerusalem 1988) pp. 356-373; and Y. BEN-NAIM, Malkhe Rabbanan (Jerusalem 1931) p. 50b, regarding several members of this family. It should also be noted that there are two extant manuscripts written by different copyists for $\mathrm{R}$. Judah Khalaz. In 1481, the Novellae of Nahmanides on Tractate Bava Metzia (MS Oxford, Bodleian Lib., Opp. Add. 4 to .67) was copied, and in 1490, the Even ha-Ezer by Judah Leon b. Moses Moskoni (MS London, Jews' College 195) was also copied. In 14901491, his work Mesiah Ilemim (MS Paris, Bibliothèque Nationale, Héb. 1334; see the description in BEIT-ARIÉ - SIRAT Manuscrits vol. 1 no. 160 n. 11) was copied for Allal b. Isaya ibn Sidon (see Gross "Khalaz" p. 357 n. 14). The last two manuscripts were copied in Tlemcen, in Algeria, where R. Judah Khalaz had settled.

30 For the distribution of the cities and towns in the Iberian Peninsula in which Hebrew books were copied, see BEINART Atlas p. 56.
} 


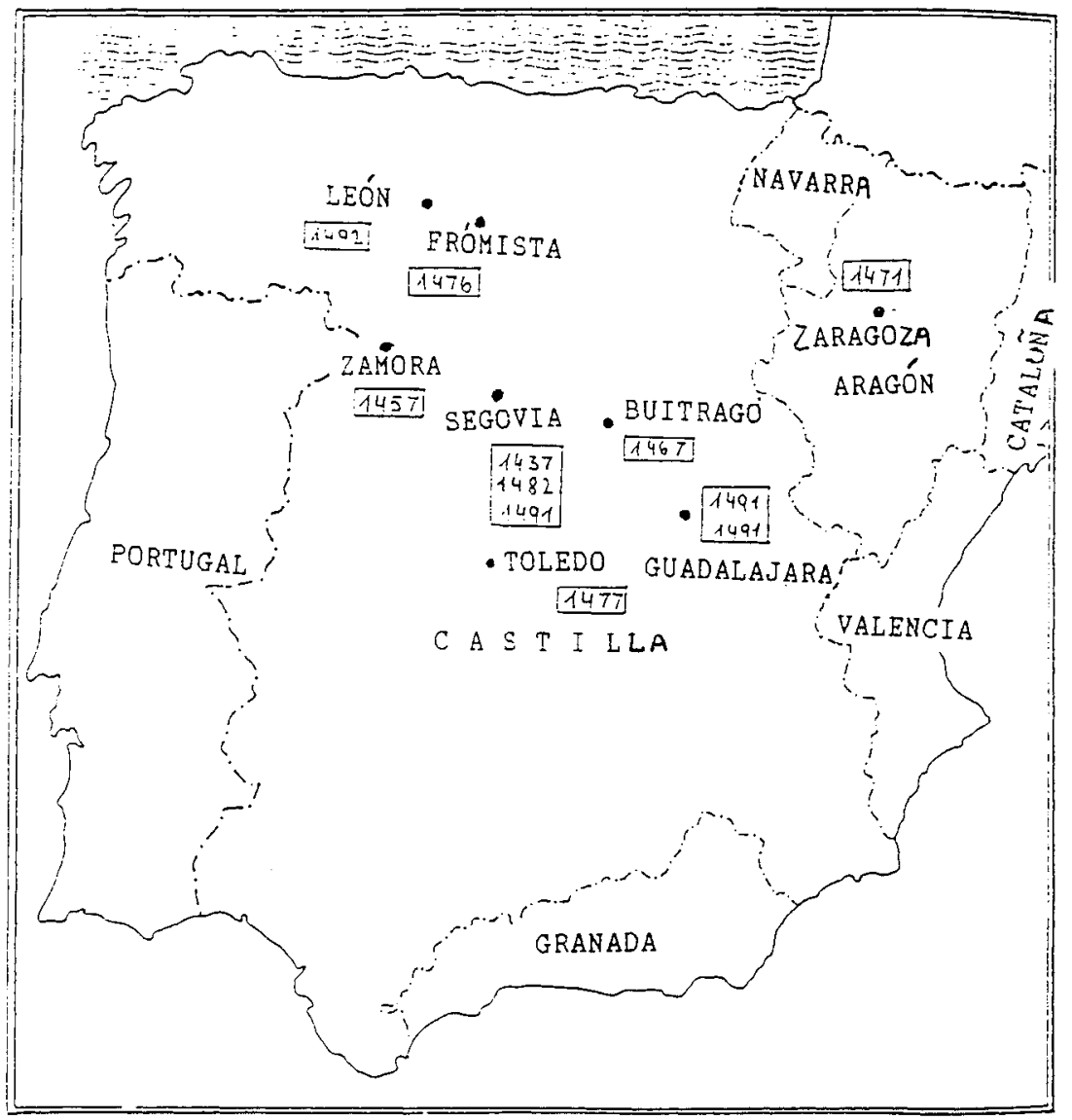

Map of yeshivot and years in which manuscripts were copied 
contribution to the history of the Spanish yeshivot, since the extant manuscripts constitute a living monument of their cultural activity.

As mentioned above, twelve colophons state explicitly that the scribe copied the manuscript in a Spanish yeshivah. These manuscripts date from the 1430s until a few months prior to the Expulsion. All the yeshivot are located in Castile, with the exception of one located in Zaragoza in Aragón ${ }^{31}$. A study of the map of the Jewish communities in Spain in the fifteenth century reveals that the yeshivot were situated in the areas most densely populated by Jews (see map).

Seven of the twelve manuscripts were copied on the initiative of some known individual. This supports evidence that an activity similar to the above-mentioned scriptoria took place in the yeshivot. Worth noting is the existence of two manuscripts copied by groups of copyists; their copy process corresponds to the Pecia system of producing books in the Middle Ages ${ }^{32}$, i.e., the segmentation of a book into booklets, such that each scribe copied his apportioned section ${ }^{33}$ in order to accelerate the completion of the work.

The yeshivot where books were produced appear according to chronological order in the following list (i.e., the date when the work was completed).

\section{Segovia ${ }^{34}$}

Three manuscripts were copied in the Segovia yeshivah, the first in 1437 , when the yeshivah was headed by the scholar Joseph ibn Shem Tov ${ }^{35}$. The colophon reads:

\footnotetext{
${ }^{31}$ For the Castilian yeshivot, see A. Gross, "A Sketch of the History of Yeshivot in Castile in the Fifteenth Century", Pe amim 31 (1987) pp. 3-21; also by the same author, "Centers of Study and Yeshivot in Spain", in Moreshet Sepharad: The Sephardi Legacy, ed. H. Beinart (Jerusalem 1992) vol. 1 pp. 399-410.

${ }^{32}$ G. Pollard, "The Pecia System in the Medieval Universities", in Medieval Scribes, Manuscripts and Libraries: Essays Presented to N. R. Ker, eds. M. B. PARKes and A. G. WATSON (London 1978) pp. 145-161.

${ }^{33}$ In these manuscripts, the changes among copyists are at times very frequent, and not necessarily related to the structure of the kuntresim.

${ }^{34}$ This name appears with different spellings, e.g.: שיגוביא, שקביא.

35 A philosopher and exegete $(1400-1460)$, the son of R. Shem Tov ibn Shem Tov. See R. Birnbaum, Joseph ben Shem Tov's Kevod Elohim: An Investigation
} 


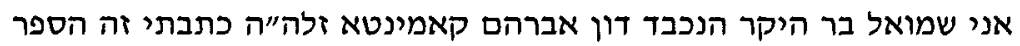

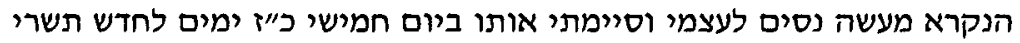

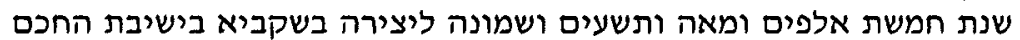

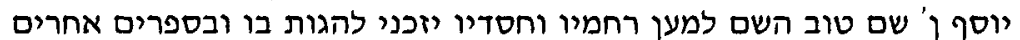
ורבים ולהבין ענינם כהוב כהוגן וכשורה אמן ולראיה חתמתי שמי שמואל בן ובסים

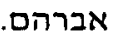

I, Samuel, son of the esteemed and honored Don Abraham Comineto, may his memory be for the life of the World to Come, wrote this book entitled Maaseh Nissim for myself, and completed it on Thursday, the 27 th day of the month of Tishri [ = 26th of Sep.], in the year five-thousand and one-hundred and ninety-eight [5198/ = 1437] of the Creation, in Segovia, at the yeshivah of the sage Joseph ibn Shem Tov. May the Lord, in His mercy and compassion, grant me the merit to study it and many other books, and to understand their subjects suitably and properly. Amen. And as proof, I sign my name, Samuel b. Abraham ${ }^{36}$.

This colophon contains the name of a pupil unknown from other sources, a disciple of the sage Joseph ibn Shem Tov. The physician Abraham Comineto, signatory of a document from 1405 in Navarra, was probably the father of the scribe ${ }^{37}$.

The second manuscript was also copied in the yeshivah, in 1482 by an anonymous scribe, apparently for his own use. The colophon reads:

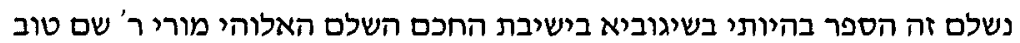
ו' שם טוב ס״ט ביום ששי כ"א ימים לחודש שבט משנת רמ״ב לאלף .[הששי].

This book was completed when I was in Segovia, in the yeshivah of the perfect and divine sage, my teacher $\mathrm{R}$. Shem Tov ibn Shem Tov, may his end be good, on Friday, the 21st day of the month of Shevat [= 11th of Jan.], in the 242nd year of the [sixth] millenium $[5242 /=1482]^{38}$.

The third manuscript was written in this yeshivah in 1491 . The copyist writes:

into the Summum Bonum of Man (Ph. D. diss. Boston University 1982); and S. REGEV, Theology and Rational Mysticism in the Writings of R. Joseph ben Shemtob (Ph. D. diss. Hebrew University, Jerusalem 1983) pp. 6-73.

${ }^{36}$ MS from the Nahum Slouschz Collection.

${ }^{37}$ See I. F. BAER, Die Juden im Christlichen Spanien (Berlin 1929) vol. 1 p. 1002 .

${ }^{38}$ MS San Francisco, Sutro Library, WPA. 149, fol. 127v. 

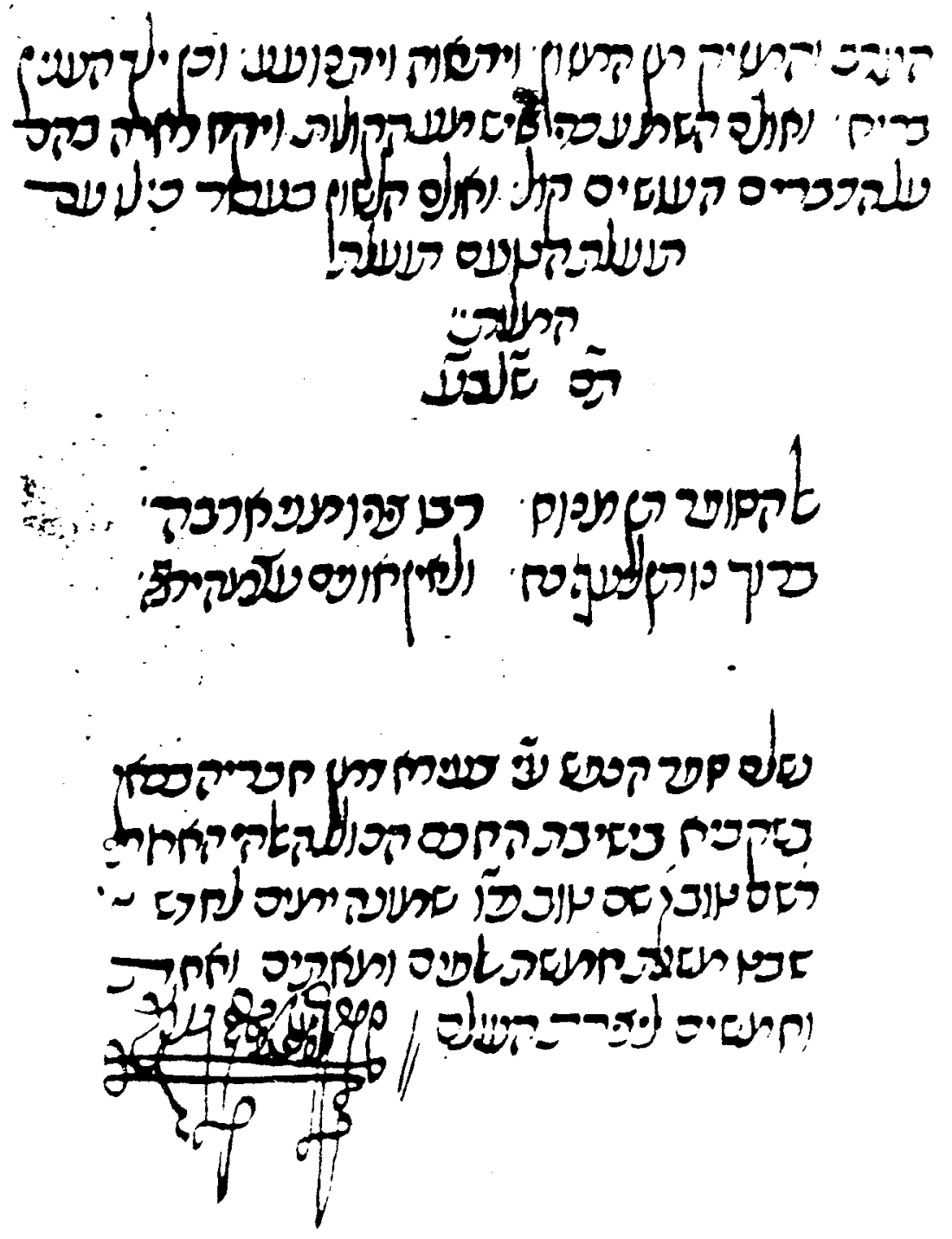

Handwriting and Colophon by Jacob b. Meir ha-Kohen. MS Freiburg, Universitätsbibliothek HS 413 , fol. 64 r (from the microfilm) 


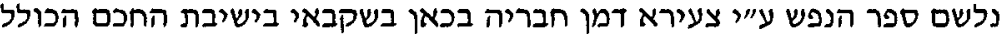

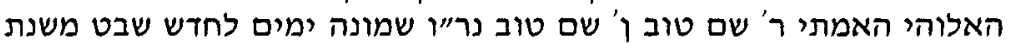

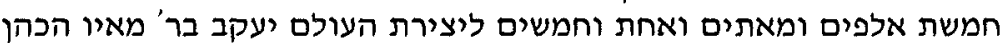

The Sefer ha-Nefesh was completed by the youngest in the group here in Segovia, in the yeshivah of the perfect and divine, the true sage ${ }^{39} \mathrm{R}$. Shem Tov ibn Shem Tov, may the Merciful One guard and bless him, [on the] eighth day of the month of Shevat $[=19$ th of Jan.], in the year five-thousand and twohundred and fifty-one [5251/=1491] of the Creation of the Universe. Jacob b. R. Meir ha-Kohen, may he rest in Paradise ${ }^{40}$.

And in another colophon of the same manuscript ${ }^{41}$, we read:

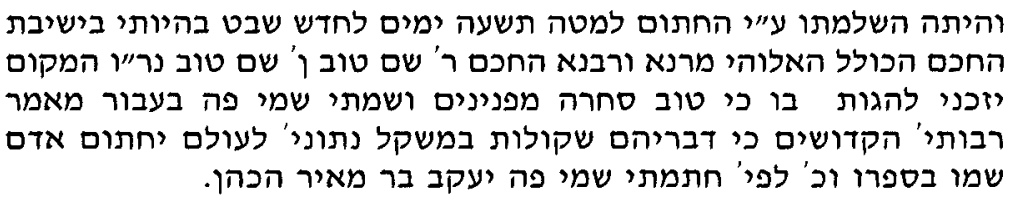

It was completed by the undersigned, [on the] ninth day of the month of Shevat [= 20th of Jan.], when I was in the yeshivah of the perfect scholar, our divine master and rabbi, the sage $\mathbf{R}$. Shem Tov ibn Shem Tov, may the Merciful One guard and bless him. May the Omnipresent allow me to study it, because its merchandise is better than pearls ${ }^{42}$. I have placed my name here under the command of our holy masters, for their words are weighed on the scales of eternity, [that] a person should sign his name in his book, etc. Accordingly, I have signed my name here, Jacob bar Meir ha-Kohen.

According to the date appearing in these colophons (the 8th-9th of Shevat, $5251 /=19-20$ th of Jan., 1491), the manuscript was completed about a year and a half before the Expulsion. Books were completed until its very eve (see below). This proves the burning desire for books at that time. Not even in the trying days and hours preceding the Expulsion, when the terrible decree already hovered above the heads of the Jews, did they cease their study of the Torah.

${ }^{39}$ The superlatives applied by the pupils to their teachers are noteworthy.

${ }^{40}$ MS Freiburg, Universitätsbibliothek HS 413, fol. 64r.

${ }^{41}$ Fol. 114r.

${ }^{42}$ Based on Prov 8:11: "For wisdom is better than rubies" and Prov 3:14: "Her value in trade is better than silvern. 
The last two manuscripts copied in the Segovia yeshivah contain different parts from the writings of Aristotle: Sefer ha-Middot ('The Book of Ethics') and Sefer ha-Nefesh ('The Book of the Soul'). This requires further explanation. It proves that the writings of Aristotle in Hebrew translation with accompanying Commentary by Averroes were in the library of the yeshivah. This is in consonance with the character of the heads of the yeshivah, the sages of the Shem Tov family, known as philosophers and interpreters of the writings of Aristotle.

These colophons also indicate that the Segovia yeshivah was active until the very eve of the Expulsion. Book copying in 1491 informs us of the activity in the yeshivah, and assures of us of its continuation from 1438 to 1491.

\section{Zamora}

In this city, there was an important yeshivah headed by the renowned rabbi Isaac Canpanton (1360-1463), about whom the Sefer Yuhasin states: "The great master, the rabbi of all Israel, our master, one of the greatest of the sages, the pious and humble, in whom the Holy Spirit of his God rests, he is the great luminary ... the gaon of Castile ... if one sees his face, it is as if receiving the Divine Presence» ${ }^{43}$. Some students of this yeshivah, such as R. Isaac de Leon, R. Isaac Aboab, and R. Samuel Valensi, would later become leading rabbis of their own yeshivot.

"The young man" Jacob b. Moses ibn Arama, the brother of $\mathbf{R}$. Isaac Arama (Zamora c. 1420 - Salonika 1494) ${ }^{44}$, author of the philosophic commentary on the Torah known as Akedat Yitzhak ${ }^{45}$ was one of the students of the yeshivah in 1454. R. Jacob copied Nahmanides' Commentary on the Torah for his brother. In the colophon, he writes:

\footnotetext{
נשלם זה הפירוש מואלה שמות לרמב"ן ז"ל כ"ד לחדש אלול שנת רניר רי"ד

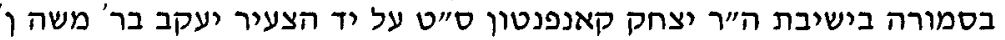

${ }^{43}$ Ed. Filipowski pp. 224 and 226; see also A. DAvid, "On R. Isaac Canpanton, One of the Great 15th Century Spanish Scholars", Kiryat Sefer 51 (1976) pp. 324-326.

${ }^{44}$ See S. HeLler-WILENSKy, The Philosophy of Isaac Arama in the Framework of Philonic Philosophy (Jerusalem - Tel Aviv 1956) [Hebrew] Introduction pp. 5-57: pp. 5-7.

${ }^{45}$ First edition printed in Salonika in 1522.
} 
This Commentary, beginning with "and these are the names" [Ex 1:1], by the Ramban of blessed memory, [on the] 24 th day of the month of Elul [ $=17$ th of Sep.] in the year $214[(5) 214 /=1454]$, was completed in Zamora, in the yeshivah of R. Isaac Canpanton (May his end be good!) by the young man Jacob b. Moses ibn Arama, for the distinguished scholar R. Isaac, my brother, may God bless him $[\ldots ?]$ with renewed strength ${ }^{46}$.

These words reveal a less-known yeshivah student, the brother of $\mathrm{R}$. Isaac Arama, who engaged in the copying of books. $\mathrm{He}$ copied the Commentary of Nahmanides on the Torah for his 34 year-old brother ${ }^{47}$, who could not possibly possess this Commentary at a prior date.

\section{Buitrago}

In this city, there was a yeshivah headed by R. Isaac Aboab $(1433-1493)^{48}$, as is indicated by a 1467 colophon. According to this new information ${ }^{49}$, he first headed the yeshivah in Buitrago, and afterwards directed another in Guadalajara ${ }^{50}$. The colophon reads:

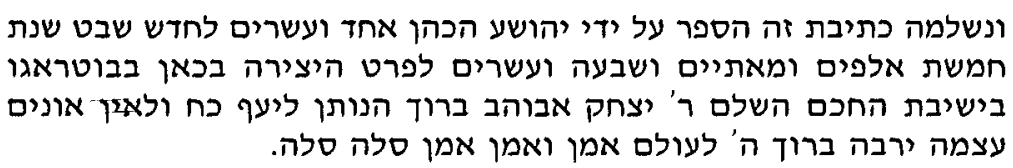

And the writing of this book has been completed by Joshua haKohen, [on the] 21st day of the month of Shevat [=27th of Jan.], in the year five-thousand and two-hundred and twenty-seventh $[5227 /=1467]$ of the Creation, here in Buitrago, in the yeshivah of the perfect sage $R$. Isaac Aboab. Blessed be the One who "gives strength to the weary and fresh vigor to the powerless" [Isa 40:29]. Blessed be the Lord forever. Amen and Amen; Amen, Selah, Selah ${ }^{51}$.

This manuscript was copied by three scribes, who frequently replace one another during the course of the copying ${ }^{52}$. The

\footnotetext{
${ }^{46}$ MS Vatican, Neof. 7, fol. 230v.

${ }^{47}$ As is indicated by a calculation based on these dates.

${ }^{48}$ D. Conforte, Kore ha-Dorot, ed. D. Cassel (Berlin 1846) pp. 28-30 and 32.

${ }^{49}$ See Gross "Yeshivot in Castile" pp. 11-12; David "Canpanton" p. 325.

${ }^{50}$ Two manuscripts were copied in this yeshivah (see below).

${ }^{51}$ MS Parma-Palatina 2372, fol. 301v.

52 Scribe 1, fols. 1-119 and 205-240; scribe 2, fols. $120-141$; scribe 3 , fols. $142-$ 204 and 241-301.
} 
author of the colophon does not specify the person for whom the Commentary of Nahmanides on the Torah was copied. Therefore, it may be assumed that this copy was prepared for one of these scribes, or that they intended to sell it sometime in the future.

The colophon was written by the scribe Joshua ha-Kohen, who also wrote the last pages of the manuscript. He prepared the third part of the manuscript. This is remarkable information. This scribe was most likely Joseph ha-Kohen's father (1496-1578?), a historiographer, physician, scribe, and linguist. The scribe Joshua ha-Kohen was among those expelled from Spain who settled in Avignon, and then moved to Genoa some years later (1501-1502). His son Joseph is the author of Divre ha-Yamim le-Malkhe Tzorfat u-le-Malkhe Bet Ottoman ha-Togar ('The History of the Kings of France and the Kings of Ottoman in Turkey') (Sabbioneta 1554) and Emek ha-Bakhah (1558). He provides autobiographical details in the introduction to the former work, in which he lists the seven generations that preceded him: "[Thus] Joseph the son of Joshua, the son of Meir, the son of Judah, the son of Joshua, the son of Judah, the son of David, the son of Moses of the kohanim ['priests'] said ..." ${ }^{53}$.

Nahmanides' Commentary on the Torah was apparently requested quite frequently, as is attested by the prior copying of this book in the yeshivah of Zamora for R. Isaac Arama (see above).

\section{Zaragoza}

As we have seen, philosophical books were in great demand among yeshivah students, and were found in the libraries of their yeshivot. The Perush Kavanot ha-Filosofim le-Abu Hamid alGhazali ('Interpretation of the Intentions of the Philosophers of Abu Hamid al-Ghazali'), by Moses Joshua Narboni, was copied by a pupil in the Zaragoza yeshivah for his own use in 1471. In the colophon, this copyist writes:

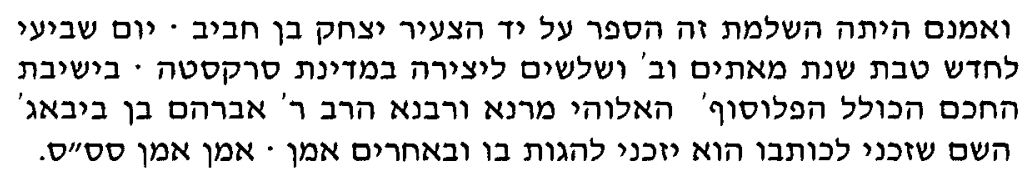

${ }^{53}$ See Sefer Divre ha-Yamim, ed. D. A. Gross (Jerusalem 1955) vol. 3 pp. 3 26; M. A. Shulvass, Jewish Life in Renaissance Italy (New York 1955) pp. 287 299 and 330-335; and Ha-Enziklopedyah ha-Ivrit vol. 19 cols. 693-694. 


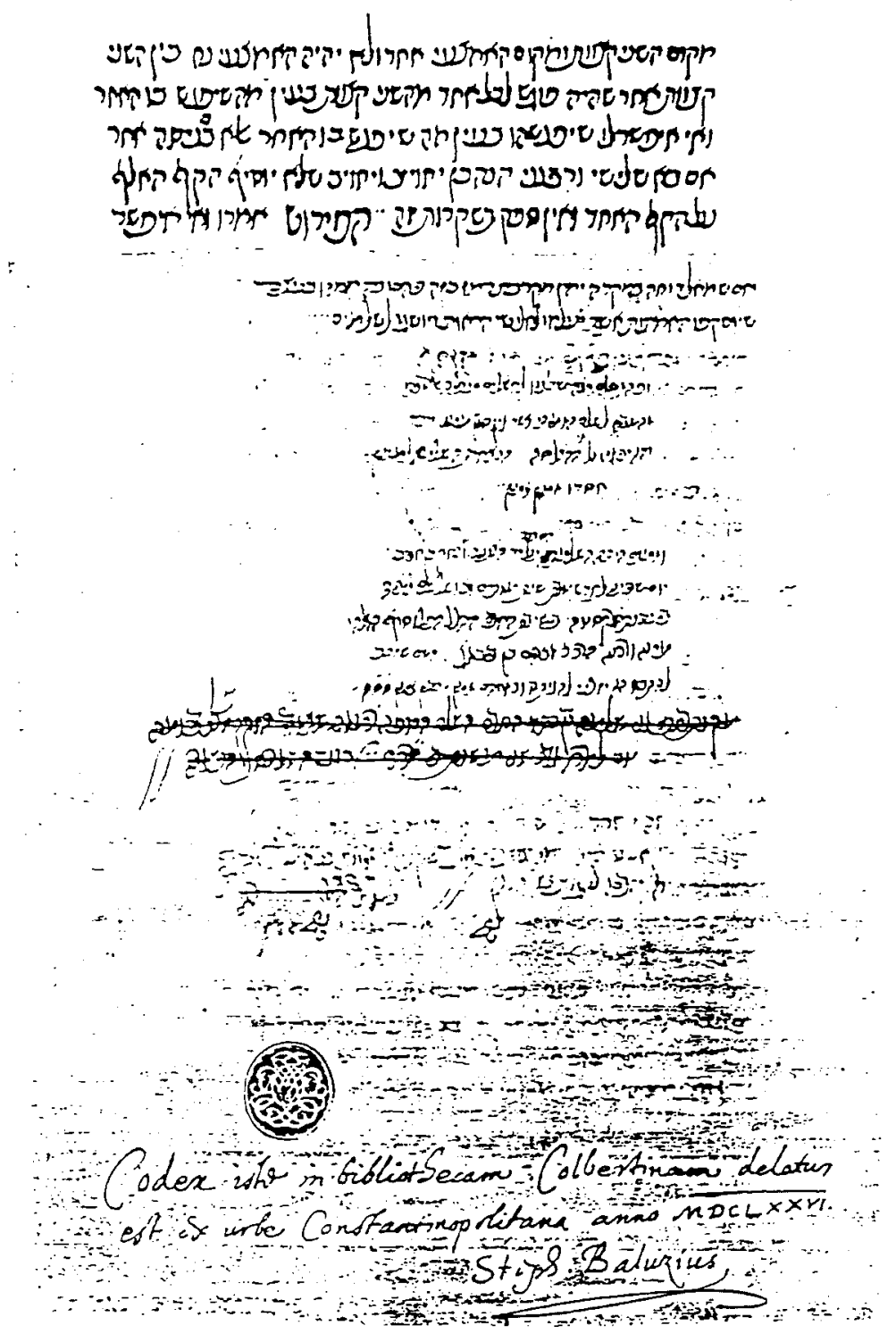

Handwriting and Colophon by Isaac b. Habib. MS Paris, Bibliothèque Nationale, Héb. 908, fol. 40v (see Arié - SiRat Manuscrits vol. 3 no. 5) 
Sef 57:2 (1997) WERE THE YESHIVOT IN SPAIN CENTERS FOR THE COPYING OF BOOKS? 391

This book was completed by the young Isaac b. Habib ${ }^{54}$, on the seventh day of the month of Tevet [ 19 th of Dec.], in the year two hundred and thirty-two $[(5) 232 /=1471]$ of the Creation, in the city of Zaragoza, in the yeshivah of the consummate sage, the divine philosopher, our master and teacher the rabbi R. Abraham b. Bibago ${ }^{55}$. May the Lord, who has enabled me to write it, allow me to study it and others, Amen. Amen, Amen, S[ela], S[ela], S[ela] ${ }^{56}$.

\section{Frómista}

In 1476, the Frómista yeshivah was headed by the sage R. Samuel Franco ${ }^{57}$, as is indicated by the colophon of a Kabbalistic collection copied in this yeshivah:

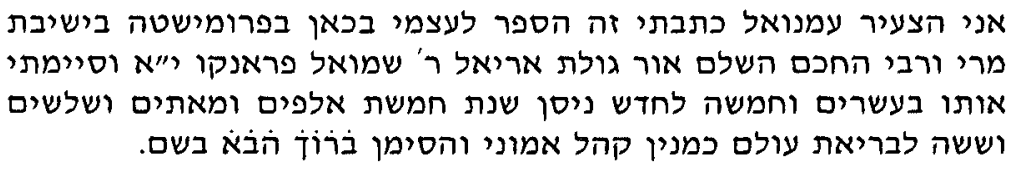

$\mathrm{I}$, the young Immanuel, wrote this book for myself, here in Frómista, in the yeshivah of my master and teacher, the perfect sage, the light of the exile of Ariel, R. Samuel Franco, may God bless him. I completed it on the 25th day of the month of Nisan [ $=19$ th of Ap.], in the year five-thousand and two-hundred and thirty-sixth [5236/=1476] of the Creation, according to the number of the members of the congregation of my faithful ${ }^{58}$, as is written "Blessed be the one who comes 236$]$ in the name [of the Lord]" [Ps 118:26] ${ }^{59}$.

${ }^{54}$ The following scholars are known to be of Spanish origin: R. Jacob ibn Habib, the author of the En Yaakov; R. Levi ibn Habib, the leading Torah scholar of Jerusalem in his time; and R. Moses ibn Habib, another "Spanish" sage in Jerusalem. The book copyist Isaac ibn Habib may be another member of this family. For R. Levi ibn Habib, see A. DAvid, "New Information on Some Personalities in Jerusalem in the 16th Century", Shalem 5 (1987) pp. 229-249: p. 240.

${ }^{55}$ The author of the Derekh Emunah. See BAER History Index; A. Nuriex, The Philosophical Teachings of R. Abraham ben Shem Tov Bibago (Ph. D. diss. Hebrew University, Jerusalem 1975); A. LAZARoFF, The Theology of Abraham Bibago (University of Alabama 1981); and J. GutTMann, "Die Familie Schemtob in ihren Beziehungen zur Philosophie», MGWJ 57 (1913) pp. 177-195: pp. 178ff.

${ }^{56}$ MS Paris, Bibliothèque Nationale, Héb. 908 , fol. 40v.

${ }^{57}$ See J. R. HACKer, "On the Intellectual Character and Self-Perception of Spanish Jewry in Late Fifteenth Century", Sefunot 17 (1983) pp. 21-95: pp. 25-26, see also the colophon and additional references.

${ }^{58}$ The intention of the scribe is unclear.

${ }^{59}$ MS Sassoon 693, fol. 197v; cf. Ohel Dawid (Oxford 1932) vol. 1 p. $427_{3}$ 
R. Samuel Franco was the teacher of R. Joseph Garçon ${ }^{60}$. After the Expulsion, Franco went to Salonika, and was one of the first and greatest sages of that community. The scribe Immanuel did not mention his family name nor provided any other lineage to identify him. However, this colophon reveals the name of a student in this renowned yeshivah.

\section{Toledo}

The yeshivah in Toledo comprised some one-hundred families, and it was the largest in Spain. It was headed by R. Isaac de Leon (d. 1486 or 1490$)^{61}$, one of the most prominent Torah scholars of his generation in the country. This institution provided scholars who later headed yeshivot of their own throughout Spain, some of whom are mentioned in this colophon.

The manuscript copied in this yeshivah in 1477 is of great interest, since it was copied by no fewer than eight scribes in the yeshivah. This fact leads us to assume the existence of a Jewish scriptoria in the yeshivah. Since none of the copyists signed his name, the identity of "the youngest of the pupils" who wrote the colophon cannot be determined. Yeshivah students probably copied the Commentary of Ha-Meiri on Proverbs for their own, or for their teacher. The book contains 209 pages, yet the author of the colophon copied most of the manuscript, whereas only a few lines to a single page were copied by his associates.

One scribe mentioned his name ("Joseph") ${ }^{62}$ in one part of the book, but he is not the author of the following colophon:

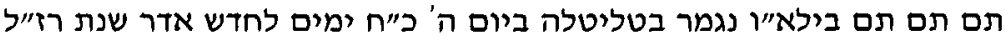

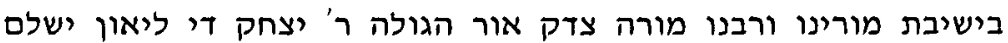
השם פועלו ותהי משכורתו שלמה מעי מעם האלורוהים וירור ויראה זרע ויאריך ימים על ידון יד יד

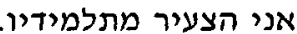

Completed, completed, completed, Blessed be the Lord forever, Amen and Amen. It was finished in Toledo on Thursday, the 28th day of the month of Adar [= 16th of Mar.], the year רליז"ז רוז', (5) $237 /=1477]^{63}$, in the yeshivah of our master and scholar, the

${ }^{60}$ For a eulogy of R. Samuel Franco, see HACKER “Intellectual» pp. 82-89.

${ }^{61}$ See J. H. WeIss, Dor Dor ve-Dorshav (Vilna 1904) vol. 5 pp. 234-235.

${ }^{62}$ In fol. $9 \mathrm{~b}$.

${ }^{63}$ This is a wordplay characteristic of many copyists, provided that the letters corresponding to the numerical value of the year of the manuscript's completion constitute a specific word. 
righteous teacher, the light of the Exile, R. Isaac de Leon. May the Lord recompense his work, may his reward be complete from the Lord ${ }^{64}$, and may he see his offspring and prolong his days ${ }^{65}$. By me, the youngest of his pupils ${ }^{66}$.

The colophon is completed by an undeciphered flowery signature $^{67}$.

\section{Guadalajara}

Nahmanides' Novellae on chapter 3 of the Tractate Sanhedrin and on the Tractate Makkot were copied in the yeshivah of Guadalajara in 1491. The scribe copied them for another student in the yeshivah, and provided the following details in a colophon:

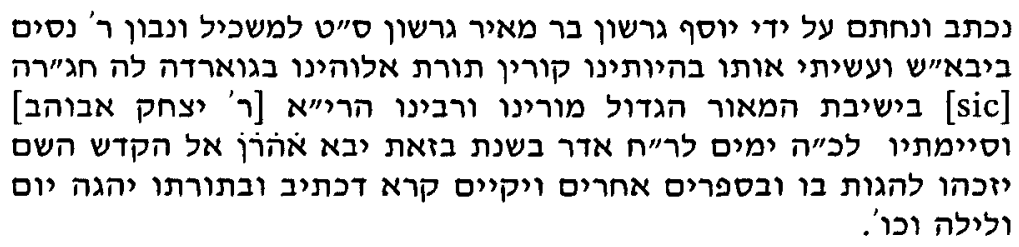

Written and completed [lit. sealed] by Joseph Gershon b. Meir Gershon ${ }^{68}$, may his end be good, for the intelligent and wise R. Nissim Bibas ${ }^{69}$. I completed this work when we were reading the Torah of our God in Guadalajara, in the yeshivah of the great luminary, our master and teacher R. I[saac] A[boab] [1433$1493]^{70}$. And I completed it on the 25 th day of the month of

${ }^{64}$ Cf. Ruth 2:12.

${ }^{65}$ Cf. Isa 53:10.

${ }^{66}$ MS Frankfort, Universitätsbibliothek MS Hebr. 8/o/56, fol. 206v.

${ }^{67}$ There are about 30 extant manuscripts from Toledo, which attest to its importance as a center of book copying. See the map of manuscripts in BeINART Atlas.

${ }^{68}$ See HACKER "Intellectual" pp. 23-25; M. Benayahu, "The Sermons of R. Yosef b. Meir Garson as a Source for the History of the Expulsion from Spain and Sephardi Diaspora", Michael 7 (1981/1982) pp. 42-205; see also Berr-ARIÉ - Sirat Manuscrits vol. 3 p. 45 no. 2.

${ }^{69}$ For the Bibas family, see J. M. Toledano, Ner ha-Maarav (Jerusalem 1989) Index; and DaviD "Information" pp. 231-233.

70 Benayahu "Sermons" p. 46 writes: “R. Joseph Garçon is not mentioned anywhere, and all that is known about him is known from his book", i.e., his sermons. This colophon informs us of the yeshivah in which he studied and his occupation as a book copyist. Benayahu adds (pp. 46-47) that ein one place Joseph Garçon cites a teaching of $\mathbf{R}$. Isaac'. According to him, the latter is $R$. Isaac de Leon, the leading Torah scholar in Castile, and head of the Salamanca yeshivah. Based on the testimony of the colophon, this "R. Isaac" may possibly 
Adar [= fifth day of Mar.] in the year "Thus only shall Aaron [הרות / 5251/=1491] come into the holy place" [Lev 16:3]. May the Lord allow him to study it and other books, so that the verse "And in His Torah he meditates day and night, etc." [cf. Ps 1:2] may be fulfilled by him ${ }^{71}$.

This yeshivah, headed by R. Isaac Aboab (1433-1493), was called "the great, the elevated, and the sublime" by its members. Many leading Spanish Torah scholars, such as R. Isaac Abrabanel, studied in this institution. The intensive book copying which took place in this yeshivah is attested by two manuscripts copied in the same year (1491), merely one year before the Expulsion. This activity may possibly have been motivated by the need to save the cultural treasures of Judaism before the disaster.

The second manuscript copied in this yeshivah includes portions of the Responsa by the Rosh (R. Asher b. Jehiel, 1250-1327). The scribe writes:

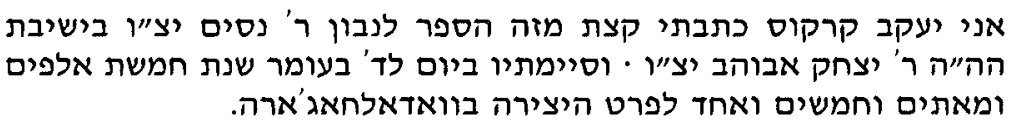

I, Jacob Corcos ${ }^{72}$, wrote a part of this book for the wise R. Nissim ${ }^{73}$, may his Rock [i.e. God] preserve and redeem him, in the yeshivah of the great and magnificent rabbi $R$. Isaac Aboab, may his Rock preserve and redeem him. And I completed it on the 34th [day] of the Omer $^{74}$ [=29th of Ap.], in the year fivethousand and two-hundred and fifty-one [5251/ = 1491] of the Creation, in Guadalajara ${ }^{75}$.

be $R$. Isaac Aboab, the head of the yeshivah in which R. Joseph Garçon acquired his rabbinical training.

${ }^{71}$ The colophon appears in A. MARX, Studies in Jewish History and Booklore (New York 1944) pp. 431-434: "Additions" pp. 431-432, but without any specification of the location of the manuscript: "... [It] was found at the end of the MS which served as a basis for the edition of Nahmanides's Commentary on Maccot, Leghorn 1745".

${ }^{72}$ For the Corcos family, see «Die Familie Corcos", $H B 11$ (1871) pp. 71-72; "Nachtrag zu den spanischen Kopisten", ZfHB 15 (1911) p. 26 n. 1; and Encyclopaedia Judaica vol. 5 cols. 960-963, wit h sources for the annals of this family. See also DAviD "Information" pp. 243-244, with references regarding this family; for the branch of the Corcos family that settled in Morocco, see Toledano Ner Index.

${ }^{73}$ R. Nissim Bibas, mentioned in the preceding manuscript.

${ }^{74}$ The 19 th of Iyyar.

${ }^{75}$ MS New York, JTS RAB. 1351 [Mic. 7081], fol. 1r. This manuscript is discussed by E. E. UrbaCH, "The Responsa of R. Asher b. Yehiel in Manuscripts and Printed Editions", Shenaton ha-Mishpat ha-Ivri 2 (1975) p. 75 n. 90. 
Sef 57:2 (1997) WERE THE YESHIVOT IN SPAIN CENTERS FOR THE COPYING OF BOOKS? 395

From this colophon we learn about R. Nissim Bibas, for whom the two manuscripts were copied. This proves that he was quite well off, because in this period most people were far from able to purchase books. The prominent Bibas family went from Spain into exile in Morocco ${ }^{76}$. The sources about this family make no mention of Nissim, and, therefore, this colophon must be the only document in which another member of this family is mentioned.

The scribe Jacob Corcos was probably a descendant of this wellknown Spanish family ${ }^{77}$. Although his name does not appear in the family annals, he may be added to its list as a book copyist. Once again, we observe that the information of the colophons is very relevant, unquestionably contributing to our knowledge of the history of the Spanish Jewry and of the Hebrew book.

\section{León}

R. Isaac Besodo ${ }^{78}$ headed a yeshivah in the city of León, where the Or ha-Shem, a commentary on the Torah by R. Mattityahu Ha-Yizhari (written in 1380) ${ }^{79}$, was copied in $1490^{80}$, i.e., two years before the Expulsion. The copyist writes:

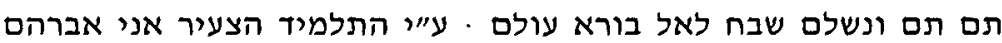

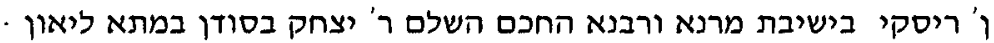

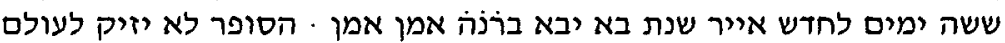

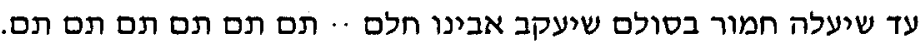

Completed, completed and finished, God the Creator of the Universe be praised, by me, the young pupil, Abraham ibn $\mathrm{Riski}^{81}$, in the yeshivah of our master and teacher, the perfect sage $\mathrm{R}$. Isaac Besodo, in the town of Leon, on the sixth day of the month of Iyyar [ $=27$ th of Ap.], in the year "He shall come

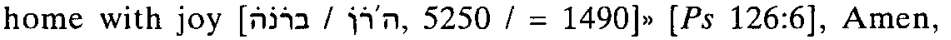
Amen. The scribe shall never cause harm until an ass ascends

\footnotetext{
${ }^{76}$ See Toledano Ner pp. 89-90 and 152-153; and Encyclopaedia Judaica vol. $4 \mathrm{col} .813$.

${ }^{77}$ See n. 72 above.

${ }^{78}$ BAER Juden vol. 2 p. 424: Juça Veçudo; and BENAYAHU "Sermons" pp. 99101.

${ }^{79}$ See BeIt-Arié - Sirat Manuscrits vol. 1 no. 504.

${ }^{80}$ For details regarding the manuscript, see AD. Neubauer, "I: R. Mattitya Ha-Yiçhari", REJ 9 (1884) pp. 116-119: p. 117 n. 2.

${ }^{81}$ I have not found any details regarding him; BAER Juden vol. 2 pp. 239 and 258 mentions a Yuce (Yuçaf) A benresq.
} 
the ladder which our father Jacob dreamt of ${ }^{82}$. Completed, completed, etc. ${ }^{83}$.

\section{Without geographical references}

There is another manuscript copied in a yeshivah in 1485 . Unfortunately, the scribe does not mention the location of the Spanish institution in which he studied and copied it. The colophon is full of details, such as the name of the person who ordered the book, the sage who headed the yeshivah, and the title of the work. However, because of the lack of any geographical reference, it is difficult to locate the place of copy. He writes:

אני יהודה בן ذjשת כתבזי זה הספר שקרא שמו באור הנרבני ועשיתי

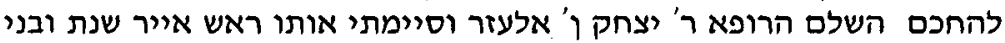
ישראל יוצאים ביד רֹה ." האל יזכהו להגות בו הוא וזרעו וזרע זרעו .. בהיותי בישיבת החכם השלם ר' חיים מנייאן • וגאמר אמן.

I, Judah Benveniste ${ }^{84}$, wrote this book, entitled Beur haNarboni ${ }^{85}$. And I prepared it for the perfect sage, the physician $R$. Isaac ibn Eleazar ${ }^{86}$, and completed it at the beginning of the month of Iyyar [first day of Iyyar $=16$ th of Ap.], in the year "and the Children of Israel went out with extended ["רמות, (5)245 $I=1485]$ hand" [Ex 14:8]. May the Lord allow him to study it, he and his offspring and his offspring's offspring. [I did this] when I was in the yeshivah of the perfect sage R. Hayyim Manion ${ }^{87}$, and let us say Amen ${ }^{88}$.

${ }^{82}$ The formula, "The scribe shall never cause any harm", is Ashkenazic, and was prevalent among the copyists from the thirteenth century onward. This seems to be a unique example of an "Ashkenazic" concluding formula in a Spanish manuscript. The scribe may possibly have copied the book from an Ashkenazic copy, or perhaps some Ashkenazic manuscripts containing this formula were in the yeshivah collections.

${ }^{83}$ MS USSR, Vilna, M. Straschun, fol. 220r, now in private hands. I want to thank Prof. Joseph Hacker for his very important comment on this manuscript. For this MS, see MARx Studies: VII. "The Expulsion of the Jews from Spain: Two New Accounts" pp. 77-106: p. 89 n. 8; and Neubauer "Ha-Yiçhari" p. 117 n. 2.

${ }^{84}$ BAER Juden vol. 2 p. 517 mentions a certain Huda Bienveniste.

${ }^{85}$ I.e., Maimonides' Guide of the Perplexed with the Commentary of R. Moses ha-Narboni.

${ }^{86}$ This physician is mentioned in the following sources: M. STEINSCHNEIDER, "Jüdische Aerzte", ZfHB 17 (1917) p. 134 n. 922; and E. Carmoly, Histoire des Médecins Juifs (Brussels 1844) p. 122.

${ }^{87}$ I have not found any details regarding this individual; BAER Juden vol. 2 p. 196 mentions an Abrahan Manion.

${ }^{88}$ MS Cambridge, Harvard University, Heb. 37, fol. 33v. This collection also includes the Maskiyot Kesef by R. Joseph b. Abba Mari ibn Caspi. This scribe also copied an additional book for the same person in the same year (MS Paris, 
Sef 57:2 (1997) WERE THE YESHIVOT IN SPAIN CENTERS FOR THE COPYING OF BOOKS? 397

\section{CONCLUSION}

The twelve manuscripts copied in Spanish yeshivot during the fifteenth century to the time of the Expulsion constitute a mosaic which depicts a previously unknown reality of the production of books in the Middle Ages. As attested by the majority of the colophons, we learn that the copying of books took place in Jewish educational institutions, not only in the home of the scribe or the person who commissioned it. Many of the copyists did not mention in the colophons that they were doing their work in a yeshivah; therefore, it is possible that other books were copied in this institution. At times, scribes would write a colophon to preserve details of importance for future generations. Consequently, the few testimonies analyzed in this article are an important contribution to the history of the Hebrew book.

The Talmud teaches that if there is a choice between certainty and uncertainty, the former is to be preferred. The lack of assurance concerning the workplace of the copyists' activity overshadows the details. Nonetheless, these colophons may clarify an aspect of Jewish cultural life both in Spain and in other lands.

Bibliothèque Nationale, Héb. 853.1). In this book, he does not specify the city nor the yeshivah in which the copying took place. 


\section{RESUMEN}

Este artículo se ocupa de la copia de manuscritos hebreos en la Península Ibérica durante la Edad Media. Los lugares geográficos que se mencionan en los colofones de los manuscritos son la base para localizar los centros de copia. Aunque se sabe muy poco sobre el ambiente de trabajo de los escribas hebreos, podría suponerse que esta actividad se llevaba a cabo en la propia casa del patrón o en la del escriba. Sin embargo, encontramos una información fundamental en los colofones escritos en Sefarad: algunos manuscritos copiados a lo largo del siglo XV hasta la expulsión lo fueron en diversas yešibot de toda España. Aquí hacemos una descripción de las yešibot, sus jefes, los escribas y las personas que solicitaban las copias. Aunque la cantidad de manuscritos que contienen esta información no es muy abundante, popdemos suponer que otros se copiaron en ambientes similares. De ser así, las yešibot serían una especie de scriptoria de judíos. Este estudio puede arrojar alguna luz sobre la cultura del libro en la Península Ibérica durante la Edad Media.

\section{SUMMARY}

The subject of this article is the copying of Hebrew manuscripts in the Iberian Peninsula in the Middle Ages. Geographical localities mentioned in the manuscripts' colophons are the basis for locating copy centers. Very little is known of the working environment of the Jewish scribes. The assumption is that this activity took place primarily in the patron's or scribe's own home. However, in the colophons from Sefarad important information can be derived; that is, that some manuscripts were copied in several yeshivot throughout Spain. This refers mainly to manuscripts copied during the 15 th century until the time of the Expulsion. Herein I describe the yeshivot, their scholars, their scribes, and the persons who ordered their copies. Although the number of manuscripts containing this information is reduced, one may assume that other manuscripts were copied in a similar environment. In effect, the yeshivot were the Jewish scriptoria. This information sheds light on the culture of the Hebrew book in the Iberian Penninsula in the waning days of the Middle Ages. 